\title{
Homofermentative production of optically pure L-lactic acid from xylose by genetically engineered Escherichia coli B
}

\author{
Jinfang Zhao', Liyuan Xu' ${ }^{1}$, Yongze Wang ${ }^{1}$, Xiao Zhao ${ }^{1}$, Jinhua Wang ${ }^{1 *}$, Erin Garza ${ }^{2}$, Ryan Manow ${ }^{2}$ \\ and Shengde Zhou ${ }^{1,2^{*}}$
}

\begin{abstract}
Background: Polylactic acid (PLA), a biodegradable polymer, has the potential to replace (at least partially) traditional petroleum-based plastics, minimizing "white pollution". However, cost-effective production of optically pure L-lactic acid is needed to achieve the full potential of PLA. Currently, starch-based glucose is used for L-lactic acid fermentation by lactic acid bacteria. Due to its competition with food resources, an alternative non-food substrate such as cellulosic biomass is needed for L-lactic acid fermentation. Nevertheless, the substrate (sugar stream) derived from cellulosic biomass contains significant amounts of xylose, which is unfermentable by most lactic acid bacteria. However, the microorganisms that do ferment xylose usually carry out heterolactic acid fermentation. As a result, an alternative strain should be developed for homofermentative production of optically pure L-lactic acid using cellulosic biomass.
\end{abstract}

Results: In this study, an ethanologenic Escherichia coli strain, SZ470 ( $\triangle$ frdBC $\Delta$ ldhA $\triangle a c k A \Delta p f l B \Delta p d h R$ ::pflBp6-acEF-Ipd $\Delta m g s A)$, was reengineered for homofermentative production of L-lactic acid from xylose (1.2 mole xylose $=>2$ mole L-lactic acid), by deleting the alcohol dehydrogenase gene (adhE) and integrating the L-lactate dehydrogenase gene (IdhL) of Pediococcus acidilactici. The resulting strain, WL203, was metabolically evolved further through serial transfers in screw-cap tubes containing xylose, resulting in the strain WL204 with improved anaerobic cell growth. When tested in $70 \mathrm{~g} \mathrm{~L}^{-1}$ xylose fermentation (complex medium), WL204 produced $62 \mathrm{~g} \mathrm{~L}^{-1} \mathrm{~L}$-lactic acid, with a maximum production rate of $1.631 \mathrm{~g} \mathrm{~L}^{-1} \mathrm{~h}^{-1}$ and a yield of $97 \%$ based on xylose metabolized. HPLC analysis using a chiral column showed that an L-lactic acid optical purity of 99.5\% was achieved by WL204.

Conclusions: These results demonstrated that WL204 has the potential for homofermentative production of L-lactic acid using cellulosic biomass derived substrates, which contain a significant amount of xylose.

Keywords: E. coli, Genetic engineering, L-lactic acid, PLA, Xylose fermentation

\section{Background}

Lactic acid, a widely used chemical, exists as a mixture of D and $\mathrm{L}$ isomers when synthesized through a chemical route [1]. The requirement of an optically pure $\mathrm{L}$ isomer for applications in pharmaceutical and poly-lactic acid (PLA) bioplastic industries favors fermentative production of L-lactic acid using chiral-specific L-lactate dehydrogenase.

\footnotetext{
* Correspondence: wangjinhua@mail.hbut.edu.cn; szhou@niu.edu ${ }^{1}$ Hubei Provincial Cooperative Innovation Center of Industrial Fermentation, Key Laboratory of Fermentation Engineering (Ministry of Education), College of Bioengineering, Hubei University of Technology, Wuhan 430068, PR China ${ }^{2}$ Department of Biological Sciences, Northern Illinois University, DeKalb, IL 60115, USA
}

Glucose derived from starch biomass such as corn, is currently used for fermentative production of L-lactic acid by lactic acid bacteria like Lactobacillus. However, due to its competition with food resources, an alternative non-food substrate is needed for cost-effective production of L-lactic acid, in order to enable the environmentally friendly PLA to compete economically with petroleum based plastics [2].

Cellulosic biomass, the most abundant non-food resource, is a potential substrate for L-lactic acid fermentation. However, in addition to glucose, the substrate (sugar stream) derived from cellulosic biomass contains significant amounts of xylose, which is unfermentable

\section{Biomed Central}


by most lactic acid bacteria [2]. The microorganisms that do ferment xylose to L-lactic acid, such as Lactococcus lactis IO-1 [3] and Enterococcus mundtii [4], need improvements in yield, productivity, optical purity, and/ or the requirement of complex nutrients.

Escherichia coli, a candidate with minimal nutrient requirements, is able to use all biomass derived hexose and pentose sugars. Derivative E. coli strains have been engineered for production of lactic acid [5-12]. However, few of these $E$. coli strains have demonstrated the ability to ferment xylose into L-lactic acid at high yields and/or optical purity. Furthermore, E. coli naturally produces D-lactic acid and lacks an endogenous L-lactate dehydrogenase gene. A plasmid bearing an exogenous L-lactate dehydrogenase gene from Streptococcus bovis [6,13], Lactobacillus casei [14], or Clostridium thermocellum [9] has been cloned into E. coli ( $p f l l d h A)$ to produce L-lactic acid. These plasmid bearing recombinants, however, may lack strain stability due to plasmid curing.

In this study, we report reengineering an ethanologenic $E$. coli strain, SZ470 ( $\triangle$ frdBC $\triangle l d h A \Delta a c k A \Delta f o c A-p f l B \Delta p d h R::$ pflBp6-pflBrbs-aceEF-lpd) [15], for homofermentative production of L-lactic acid from xylose. The resulting strain, WL204, contains a chromosomal integrated ldhL gene, without any antibiotic marker or plasmids.

\section{Results and discussion}

\section{Eliminate ethanol pathway}

E. coli SZ470 ( $\triangle$ frdBC $\triangle l d h A \triangle a c k A \Delta p f l B \Delta p d h R:: p f l B p 6-$ acEF-lpd $\triangle m g s A$ ), a xylose fermenting homoethanol strain previously engineered from $E$. coli $\mathrm{B}$, was selected for reengineering to produce L-lactic acid using xylose. The ethanol pathway of SZ470 was eliminated through deletion of the endogenous alcohol dehydrogenase gene ( $a d h E)$ using the $a d h E^{\prime}$-FRT-kan-FRT-adhE' DNA fragment and the $\lambda$ red recombinase system $[10,16]$. The antibiotic marker (kan) of the resulting kanamycin resistant colonies was then removed from the chromosome through FRTrecognizing site specific recombinase (flipase), producing the strain WL202 ( $\Delta a d h E:: F R T)$ which lacks the ethanol pathway and antibiotic marker.

Fermentation tests showed that WL202 lost its ability to produce ethanol and anaerobic cell growth, indicating $a d h E$ was successfully deleted. The loss of anaerobic growth was expected since the only NADH oxidation pathway (through the ethanol pathway) of WL202 was blocked by deletion of adhE (Figure 1).

\section{Establish lactate pathway}

To regain anaerobic growth and the ability to produce L-lactic acid by WL202, a L-(+)-lactate dehydrogenase enzyme was needed to convert pyruvate to L-lactate and oxidize $\mathrm{NADH}$, and establish a homolactate pathway with a balanced NADH/NAD redox (1 glucose or 1.2 xylose +2 NAD (glycolysis) $=>2$ pyruvate $+2 \mathrm{NADH}$ (L-lactate dehydrogenase $)=>2$ L-lactate +2 NAD) (Figure 1). To this end, the L-(+)-lactate dehydrogenase gene $(l d h L)$ of Pediococcus acidilactici was amplified by PCR using E. coli SZ85 chromosomal DNA as the template (a strain containing integrated $l d h L$ ) [17]. The amplified DNA fragment contained the $l d h L$ coding region flanked by the promoter and terminator of the native E. coli ldhA gene. This hybrid DNA fragment (ldhA promoter-ldhL -ldhA terminator) was then

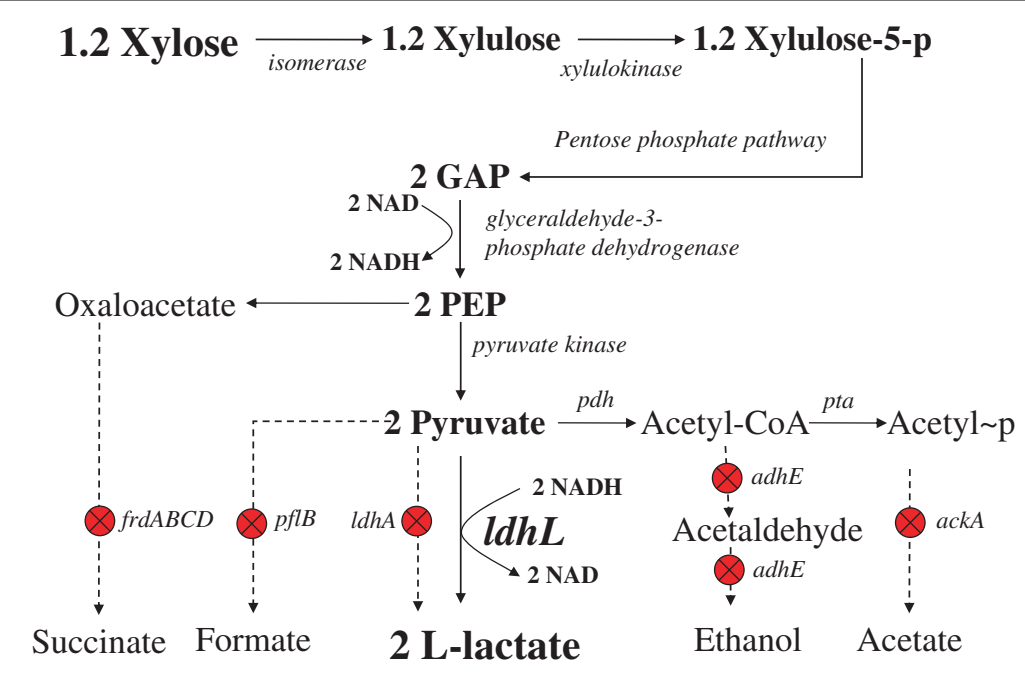

Figure 1 Engineering a xylose-to-L-lactic acid homofermentative pathway (1.2 mole xylose $=>\mathbf{2}$ mole L-lactic acid). Genes encoding important enzymes are indicated by italics. The relevant gene encoding enzymes are: $p d h$, pyruvate dehydrogenase complex (engineered for anaerobic expression in a previous study); pta, phosphotransacetylase; adhE, alcohol dehydrogenase; ackA, acetate kinase; IdhA, D-lactate dehydrogenase; IdhL, L-lactate dehydrogenase (expressed from IdhA promoter); pflB, pyruvate formate lyase; frdABCD, fumurate reductase. The abbreviated metabolic intermediates are: GAP, glyceraldehyde-3-phosphate; PEP, phosphoenol pyruvate. The stop sign indicated the relevant gene was deleted. 

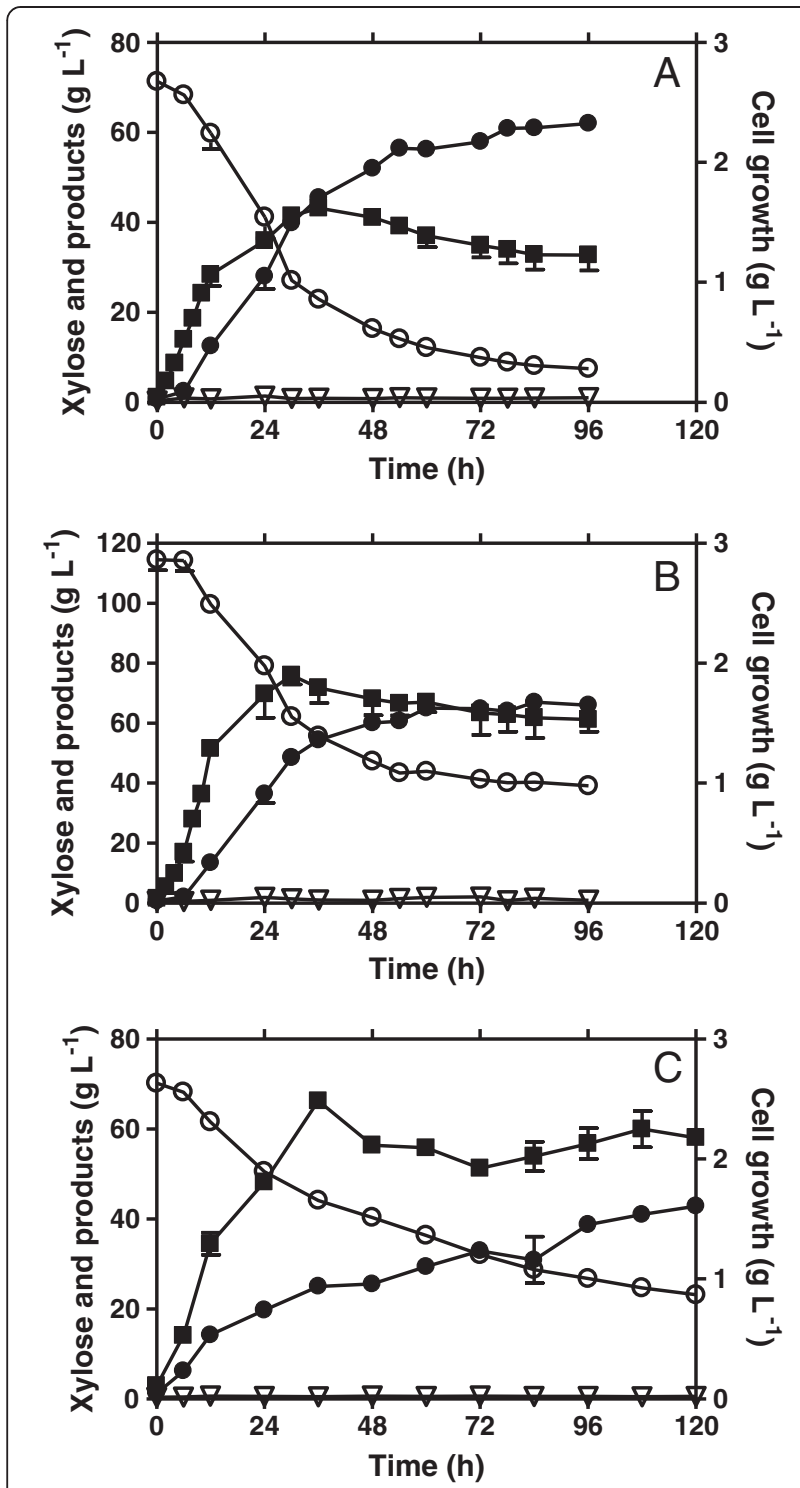

Figure 2 L-lactic acid fermentation from xylose. A) $70 \mathrm{~g} \mathrm{~L}^{-1}$ xylose LB medium; B) $100 \mathrm{~g} \mathrm{~L}^{-1}$ xylose LB medium; C) $70 \mathrm{~g} \mathrm{~L}^{-1}$ xylose NBS medium. Symbols: open circle, xylose; filled circle, lactic acid; filled square, cell growth; triangle, acetic acid. Each data point is the average of three replicates with the error bar representing the standard deviation. transformed into WL202 (pKD46) through electroporation. The double homologous recombination with $l d h L$ integrated at the $l d h A$ locus was selected through anaerobic cell growth in screw-cap tubes. The temperature sensitive plasmid, pKD46, was then cured by incubation at $42^{\circ} \mathrm{C}$. The resulting strain was designated WL203 $(\Delta l d h A:: l d h L)$.

WL203 produced L-lactic acid from xylose in screw cap tubes and in small scale fermentation with limited anaerobic growth $\left(\mathrm{OD}_{600 \mathrm{~nm}}\right.$ of 0.5-1.0 after $\left.24 \mathrm{~h}\right)$. A growth based metabolic evolution process was then carried out by growing and serial transferring (at $24 \mathrm{~h}$ intervals) WL203 in a LB-xylose medium for three months, resulting in strain WL204 with a one-fold improvement in anaerobic cell growth in screw cap tubes.

\section{L-lactic acid production from xylose}

L-lactic acid production by $E$. coli WL204 was evaluated using a 7-L fermenter containing $70 \mathrm{~g} \mathrm{~L}^{-1}$ xylose (pH 7.0, $37^{\circ} \mathrm{C}$ ). The results are shown in Figure $2 \mathrm{~A}$ and Table 1. During the initial $12 \mathrm{~h}$ fermentation, WL204 achieved the maximum growth rate of $0.271 \mathrm{~h}^{-1}$, and then continued to grow at a lower rate for another $24 \mathrm{~h}$, reaching the maximum biomass of $1.619 \mathrm{~g} \mathrm{~L}^{-1}$. There was little lactic acid produced for the first $6 \mathrm{~h}$ while the cell was actively growing up to one third of the maximum biomass. Nevertheless, $39 \mathrm{~g} \mathrm{~L}^{-1}$ lactic acid was produced in the following $24 \mathrm{~h}$ production period $(6 \mathrm{~h}-30 \mathrm{~h})$, maintaining the maximum production rate of $1.631 \mathrm{~g} \mathrm{~L}^{-1}$. Lactic acid was continuously produced at a lower rate for the next $48 \mathrm{~h}(36 \mathrm{~h}-78 \mathrm{~h})$, achieving an average production rate of $\sim 0.78 \mathrm{~g} \mathrm{~L}^{-1}$ and a final titer of $62 \mathrm{~g} \mathrm{~L}^{-1}$ for the active production period $(0 \mathrm{~h}-78 \mathrm{~h})$. Little lactic acid, if any, was produced thereafter even though there was $7.48 \mathrm{~g} \mathrm{~L}^{-1}$ xylose still available. Nevertheless, a 97\% theoretical yield was achieved based on the xylose metabolized, indicating that xylose was converted to lactic acid at a nearly perfect 1:1.667 molar ratio, with little acetic acid $\left(\sim 1 \mathrm{~g} \mathrm{~L}^{-1}\right)$ produced as a by-product.

Table 1 Summary of xylose fermentations by E. coli WL204

\begin{tabular}{|c|c|c|c|c|c|c|c|c|c|}
\hline \multirow[t]{2}{*}{$\begin{array}{l}\text { Xylose } \\
\left(g^{-1}\right)\end{array}$} & \multicolumn{2}{|c|}{ Cell growth } & \multicolumn{2}{|c|}{ Lactic acid } & \multicolumn{2}{|c|}{$\begin{array}{l}\text { Volumetric productivity } \\
\qquad\left(\mathrm{g} \mathrm{L}^{-1} \mathrm{~h}^{-1}\right)\end{array}$} & \multicolumn{2}{|c|}{$\begin{array}{l}\text { Specific productivity } \\
\qquad\left(\mathrm{g} \mathrm{g} \mathrm{g}^{-1} \mathrm{~h}^{-1}\right)\end{array}$} & \multirow{2}{*}{$\begin{array}{c}\text { By-product } \\
\text { (Acetic acid) } \\
\left(\mathrm{g} \mathrm{L}^{-1}\right)\end{array}$} \\
\hline & Mass $\left(\mathrm{g} \mathrm{L}^{-1}\right)$ & Rate $^{1)}\left(h^{-1}\right)$ & Titer $\left(\mathrm{g} \mathrm{L}^{-1}\right)$ & Yield $^{2)}(\%)$ & Maximum $^{3)}$ & Average $^{4)}$ & Maximum $^{3)}$ & Average $^{4)}$ & \\
\hline $70(\mathrm{LB})$ & $1.619 \pm 0.112$ & $0.271 \pm 0.032$ & $62.04 \pm 0.92$ & 97 & $1.631 \pm 0.039$ & $0.780 \pm 0.017$ & $1.05 \pm 0.032$ & $0.623 \pm 0.097$ & $1.01 \pm 0.383$ \\
\hline $100(\mathrm{LB})$ & $1.901 \pm 0.110$ & $0.291 \pm 0.030$ & $66.03 \pm 1.51$ & 90 & $1.934 \pm 0.011$ & $1.092 \pm 0.010$ & $1.02 \pm 0.054$ & $0.653 \pm 0.052$ & $0.992 \pm 0.087$ \\
\hline 70 (NBS) & $2.487 \pm 0.150$ & $0.205 \pm 0.020$ & $42.9 \pm 0.80$ & 91 & $0.768 \pm 0.021$ & $0.358 \pm 0.012$ & $0.309 \pm 0.018$ & $0.144 \pm 0.010$ & $0.596 \pm 0.026$ \\
\hline
\end{tabular}


Table 2 Comparison of $E$. coli strains engineered for L-lactic acid production using xylose

\begin{tabular}{|c|c|c|c|c|c|c|c|c|}
\hline \multirow[t]{2}{*}{ Strains } & \multirow[t]{2}{*}{ IdhL location } & \multirow[t]{2}{*}{ Medium } & \multirow{2}{*}{$\begin{array}{l}\text { Initial xylose } \\
\quad\left(\mathrm{g} \mathrm{L}^{-1}\right)\end{array}$} & \multicolumn{4}{|c|}{ L-lactic acid } & \multirow[t]{2}{*}{ Reference } \\
\hline & & & & Titer $\left(\mathrm{g} \mathrm{L}^{-1}\right)$ & Productivity $\left(\mathrm{g} \mathrm{L}^{-1} \mathrm{~h}^{-1}\right)$ & Yield (\%) & Optical purity (\%) & \\
\hline E. coli FBR9 & plasmid & complex & 100 & 56 & 0.47 & 84 & $\mathrm{n} / \mathrm{a}$ & [14] \\
\hline E. coli FBR11 & plasmid & complex & 100 & 63 & 0.73 & 89 & $\mathrm{n} / \mathrm{a}$ & [14] \\
\hline E. coli FBR19 & plasmid & complex & 40 & 32 & $\mathrm{n} / \mathrm{a}$ & 88 & $\mathrm{n} / \mathrm{a}$ & [6] \\
\hline E. coli SZ85 & chromosome & minimal & 50 & 40 & 0.32 & 93 & 99.5 & {$[17]$} \\
\hline E. coli WL204 & chromosome & complex & 100 & 66 & 1.09 & 90 & 99.5 & This study \\
\hline
\end{tabular}

$100 \mathrm{~g} \mathrm{~L}^{-1}$ xylose fermentation was also carried out to evaluate if osmotic pressure (from xylose) would be a challenge for cell growth and lactic acid production by WL204. As the results show in Figure 2B and Table 1, the patterns of cell growth, xylose consumption and lactic acid production were similar to those of the $70 \mathrm{~g} \mathrm{~L}^{-1}$ xylose fermentation. The cell growth rate $\left(0.291 \mathrm{~h}^{-1}\right)$, biomass $\left(1.901 \mathrm{~g} \mathrm{~L}^{-1}\right)$, and the maximum $\left(1.934 \mathrm{~g} \mathrm{~L}^{-1} \mathrm{~h}^{-1}\right)$ and average $\left(1.092 \mathrm{~g} \mathrm{~L}^{-1} \mathrm{~h}^{-1}\right)$ volumetric productivities of $100 \mathrm{~g} \mathrm{~L}^{-1}$ xylose fermentation were $7.4 \%, 17.4 \%$, $18.6 \%$, and $40 \%$ higher, respectively, than those of the $70 \mathrm{~g} \mathrm{~L}^{-1}$ xylose fermentation, demonstrating that osmotic pressure from $100 \mathrm{~g} \mathrm{~L}^{-1}$ xylose presented little challenge for WL204. However, the $66 \mathrm{~g} \mathrm{~L}^{-1}$ lactic acid titer achieved was almost the same as that achieved
(62 $\mathrm{g} \mathrm{L}^{-1}$ ) in the $70 \mathrm{~g} \mathrm{~L}^{-1}$ xylose fermentation, indicating that 62-66 $\mathrm{g} \mathrm{L}^{-1}$ lactate inhibited WL204 from further growth and fermentation.

WL 204 was further evaluated for its ability for L(+)-lactic acid production in mineral salts medium using $70 \mathrm{~g} \mathrm{~L}^{-1}$ xylose NBS fermentation. As demonstrated in Figure 2C and Table 1, the engineered WL204 maintained its ability to grow and produce lactic acid with over $90 \%$ product yield in mineral salts medium. However, cell growth rate, product titer, and productivity achieved in mineral salts medium (NBS) were 32\%, 44\%, and 117\% lower, respectively, than those obtained in complex LB medium under the same condition, suggestion that WL204 needs further adaptive evolution to improve its growth rate and lactic acid production in NBS medium.

Table 3 E. coli strains, plasmids and primers used in this study

\begin{tabular}{|c|c|c|}
\hline Strains & Relevant characteristics & Sources \\
\hline SZ470 & E. coli B, $\Delta$ frdBC $\Delta / d h A \Delta a c k A \Delta p f l B \Delta p d h R$ ::pflBp6-acEF-lpd $\Delta m g s A$ & [15] \\
\hline SZ85 & E. coli W3110, $\triangle$ focA-pflB $\triangle$ frdBC $\triangle$ adhE $\triangle a c k A \triangle I d h A: \cdot / d h L$ & [17] \\
\hline WL202 & SZ470, $\triangle a d h E$, lost anaerobic growth & This study \\
\hline WL203 & WL202, $\Delta / d h A: \cdot I d h L$, regained anaerobic growth & This study \\
\hline WL204 & WL203, metabolically evolved in xylose with improved anaerobic growth & This study \\
\hline \multicolumn{3}{|l|}{ Plasmid } \\
\hline pKD4 & FRT-kan-FRT cassette & [16] \\
\hline pKD46 & bla, red recombinase, temperature-dependent replication & {$[16]$} \\
\hline pFT-A & bla, flp, temperature-dependent replication & {$[20]$} \\
\hline \multicolumn{3}{|l|}{ Primers } \\
\hline Clone $/ d h L-P 1$ & CCTATTATTATGGCGGTGTCGTTT & This study \\
\hline Clone IdhL-P2 & CAGTTCGCTGACTGTAAGTTGTTGC & This study \\
\hline \multirow[t]{2}{*}{ Delete adhE-P1 } & ATGGCTGTTACTAATGTCGCTGAACTTAACGCAC & This study \\
\hline & TCGTAGAGCGTGTGTAGGCTGGAGATGCTTC ${ }^{1)}$ & \\
\hline \multirow[t]{2}{*}{ Delete adhE-P2 } & TTAAGCGGATTITTCGCTTITTCTCAGCTTTAG & This study \\
\hline & CCGGAGCAGCCATATGAATATCCTCCTTAG ${ }^{1)}$ & \\
\hline Verify $\triangle a d h E-P 1$ & TGATGAAGGCTAATGCTG & This study \\
\hline Verify $\triangle a d h E-P 2$ & CTTACGCCACCTGGAAGT & This study \\
\hline Verify insertion IdhL-P1 & GGTTCTAGTTACGCATTCG & This study \\
\hline Verify insertion IdhL-P2 & CTTCTTCTTTTCGTCATCG & This study \\
\hline
\end{tabular}

1. The bold sequence is homologous to the flanked sequence of the FRT-kan-FRT cassette in pKD4. 


\section{Optical purity of L-lactic acid}

Only the L-lactic acid isomer was detected in the fermentation product when analyzed by HPLC using a chiral column. However, a D-isomer peak was observed if it was intentionally added into the fermentation product at a ratio of $0.5 \%$ of the total lactic acid. These results indicated that the optical purity of L-lactic acid produced was at least $99.5 \%$.

\section{Conclusions}

The current biocatalysts used for commercial L-lactic acid production are either unable to metabolize xylose or they metabolize xylose through phosphoketolase, which leads to a heterofermentative pathway of equal molar lactic acid and acetic acid [18]. Attempting to engineer homolactic acid production from xylose has met limited success in lactic acid bacteria $[18,19]$ and in E. coli strains $[6,14,17]$.

By deleting the alcohol dehydrogenase gene $(a d h E)$ of a previously engineered xylose fermenting ethanologenic $E$. coli strain, and integrating an $l d h L$ gene into the chromosome, we successfully engineered an L-lactic acid producing strain, WL204, which produced 62-66 $\mathrm{g} \mathrm{L}^{-1}$ L-lactic acid, has a productivity of 1.631-1.934 $\mathrm{g} \mathrm{L}^{-1}$, a yield of 90-97\%, and an optical purity of $99.5 \%$ from xylose fermentation (complex medium). These results are favorable when compared to those achieved by the prior reported E. coli strains for L-lactic acid fermentation from xylose (Table 2). Nevertheless, further improvement of lactic acid tolerance, growth rate and productivity in mineral salts medium of WL204 is needed to achieve a cost effective titer $\left(\geq 100 \mathrm{~g} \mathrm{~L}^{-1}\right)$ for practical applications.

\section{Methods}

\section{Strains, plasmids and growth conditions}

The bacterial strains, plasmids, and primers used in this study are listed in Table 3. Bacterial cultures were grown at $37^{\circ} \mathrm{C}$ in Luria-Bertani (LB) broth $\left(\mathrm{g} \mathrm{L}^{-1}\right.$ : tryptone 10 , yeast extract 5 , and $\mathrm{NaCl} 5$ ) supplemented with $20 \mathrm{~g} \mathrm{~L}^{-1}$ xylose, or on LB plates (agar $20 \mathrm{~g} \mathrm{~L}^{-1}$ ) containing $20 \mathrm{~g} \mathrm{~L}^{-1}$ xylose. $50 \mu \mathrm{g} \mathrm{ml}^{-1}$ kanamycin or ampicillin was added into the medium as needed during strain construction [10]. Fermentations were carried out in both complex LB medium and mineral salts medium (NBS medium $\left(\mathrm{g} \mathrm{L}^{-1}\right): \mathrm{KH}_{2} \mathrm{PO}_{4}$, 3.5; $\mathrm{K}_{2} \mathrm{HPO}_{4}, 5.0 ;\left(\mathrm{NH}_{4}\right)_{2} \mathrm{HPO}_{4}, 3.5 ; \mathrm{MgSO}_{4}: 7 \mathrm{H}_{2} \mathrm{O}, 0.25$; $\mathrm{CaCl}_{2}: 2 \mathrm{H}_{2} \mathrm{O}, 0.015$; thiamine, 0.0005 ; and $1 \mathrm{~mL}$ of trace metal stock). The trace metal stock was prepared as previously described [10].

\section{Genetic methods}

Standard methods were used for DNA transformation, electroporation, PCR amplification, and analyses of DNA fragments. Chromosomal gene deletion and integration was carried out using previously described $\lambda$ red homologous recombination procedures $[10,17]$. The gene deletions and integrations were verified by using appropriate antibiotic markers and analysis of PCR and fermentation products.

\section{Fermentations}

Seed cultures were prepared by inoculating fresh colonies from LB-xylose plates into $500 \mathrm{ml}$ flasks containing $200 \mathrm{ml}$ LB medium with $2 \%(\mathrm{w} / \mathrm{v})$ xylose, and incubated for $10 \mathrm{~h}$ $\left(37^{\circ} \mathrm{C}, 150 \mathrm{rpm}\right)$ until they achieved an $\mathrm{OD}_{600 \mathrm{~nm}}$ of $\sim 1.9$ (0.665 $\mathrm{g} \mathrm{L}^{-1}$ cell dry weight). Seed cultures were inoculated (with a starting $\mathrm{OD}_{600 \mathrm{~nm}}$ of 0.1 ) into a 7-L fermenter (Sartorius Stedim Biotech GmbH 37070, Germany) containing 4-L LB medium with $70 \mathrm{~g} \mathrm{~L}^{-1}$ xylose. The fermentation was carried out for $96 \mathrm{~h}\left(37^{\circ} \mathrm{C}, 200 \mathrm{rpm}\right.$, and $\mathrm{pH}$ 7). The $\mathrm{pH}$ was controlled by automatic addition of $6 \mathrm{~N} \mathrm{KOH}$. Samples $(1.5 \mathrm{ml})$ were taken periodically for analysis of cell growth, sugar consumption and lactic acid production. Data presented were the averages of three replicated fermentations.

\section{Analysis}

Cell growth was estimated from the optical density (1-L cells with an $\mathrm{OD}_{600 \mathrm{~nm}}$ of 1 is equivalent to $0.35 \mathrm{~g}$ dry cell weight). Fermentation samples were centrifuged at $8,000 \mathrm{rpm}$ for 10 $\mathrm{min}$. The supernatant was then filtered through a $0.22 \mu \mathrm{m}$ membrane, and used for HPLC analysis of sugar and organic acids concentrations (BioRad HPX $87 \mathrm{H}$ column, $35^{\circ} \mathrm{C}$, $0.5 \mathrm{ml} \mathrm{min}^{-1}$ of $4 \mathrm{mM} \mathrm{H}_{2} \mathrm{SO}_{4}$ as the mobile phase). Optical purity was determined by HPLC using a chiral column (EC 250/4 NUCLEOSIL Chiral-1, Germany) $\left(35^{\circ} \mathrm{C}, 0.5 \mathrm{ml}\right.$ $\mathrm{min}^{-1}$ of $0.2 \mathrm{mM} \mathrm{CuSO}_{4}$ as the mobile phase) and D (-) and $\mathrm{L}(+)$-lactic acids (Sigma-Aldrich) as the standards.

\section{Competing interests}

The authors declare that they have no competing interests.

\section{Authors' contribution}

JZ, LZ and YW carried out the genetic modification; XZ and JW participated the fermentation; EG, RM and SZ summarized the data and wrote the manuscript. All authors read and approved the final manuscript.

\section{Acknowledgements}

This work was supported by a grant from the China National Natural Science Foundation (NSFC31070094), the Hubei Provincial Science Foundation (2011CDA008), the Chutian Scholar Program, Hubei University of Technology, P. R. China, and Northern Illinois University, USA.

Received: 17 January 2013 Accepted: 21 May 2013

Published: 7 June 2013

\section{References}

1. Datta $R$, Henry M: Lactic acid: recent advances in products, processes and technologies-a review. J Chem Technol Biotechnol 2006, 81(7):1119-1129.

2. Hofvendahl $\mathrm{K}$, Hahn-Hagerdal B: Factors affecting the fermentative lactic acid production from renewable resources. Enzyme Microb Technol 2000, 26:87-107.

3. Tanaka K, Komiyama A, Sonomoto K, Ishizaki A, Hall S, Stanbury P: Two different pathways for D-xylose metabolism and the effect of xylose concentration on the yield coefficient of L-lactate in mixed-acid fermentation by the lactic acid bacterium Lactococcus lactis 10-1. Appl Microbiol Biotechnol 2002, 60(1):160-167.

4. Abdel-Rahman MA, Tashiro Y, Zendo Hanada K, Shibata K, Sonomoto K: Efficient homofermentative $L(+)$-lactic acid production from xylose by a 
novel lactic acid bacterium, Enterococcus mundtii QU25. Appl Environ Microbiol 2011, 77(5):1892-1895.

5. Chang $D E$, Jung $H C$, Rhee JS, Pan JG: Homofermentative production of D- or L-lactate in metabolically engineered Escherichia coli RR1. Appl Environ Microbiol 1999, 65:1384-1389.

6. Dien BS, Nichols NN, Bothast RJ: Fermentation of sugar mixtures using Escherichia coli catabolite repression mutants engineered for production of L-lactic acid. J Ind Microbiol Biotechnol 2002, 29(5):221-227.

7. Grabar TB, Zhou S, Shanmugam KT, Yomano LP, Ingram LO: Methylglyoxal bypass identified as source of chiral contamination in $L(+)$ and $D$ (-)-lactate fermentations by recombinant Escherichia coli. Biotechnol Lett 2006, 28:1527-1535.

8. Mazumdar S, Clomburg JM, Gonzalez R: Escherichia coli strains engineered for homofermentative production of d-lactic acid from glycerol. Appl Environ Microbiol 2010, 76(13):4327-4336.

9. Ozkan M, Yllmaz El, Lynd LR, Ozcengiz G: Cloning and expression of the Clostridium thermocellum L-lactate dehydrogenase gene in Escherichia coli and enzyme characterization. Canadian J Microbiol 2004, 50(10):845-851.

10. Wang Y, Tian T, Zhao J, Wang J, Yan T, Xu L, Liu Z, Garza E, Iverson A, Manow R, Finan C, Zhou S: Homofermentative production of d-lactic acid from sucrose by a metabolically engineered Escherichia coli. Biotechnol Lett 2012, 34(11):2069-25.

11. Zhou S, Yomano LP, Shanmugam KT, Ingram LO: Fermentation of $10 \%$ (w/v) sugar to D-lactate by engineered Escherichia coli B. Biotechnol Lett 2005, 27:1891-1896.

12. Zhu Y, Eiteman MA, DeWitt K, Altman E: Homolactate fermentation by metabolically engineered Escherichia coli strains. Appl Environ Microbiol 2007, 73(2):456-464.

13. Wyckoff HA, Chow J, Whitehead TR, Cotta MA: Cloning, sequence, and expression of the L-(+)-lactate dehydrogenase of Streptococcus bovis. Current Microbiol 1997, 34(6):367-373.

14. Dien BS, Nichols NN, Bothast RJ: Recombinant Escherichia coli engineered for production of L-lactic acid from hexose and pentose sugars. $J$ Ind Microbiol Biotechnol 2001, 27(4):259-264.

15. Wang Y, Manow R, Finan C, Wang J, Garza E, Zhou S: Adaptive evolution of nontransgenic Escherichia coli KCO1 for improved ethanol tolerance and homoethanol fermentation from xylose. J Ind Microbiol Biotechnol 2011, 38(9):1371-1377.

16. Datsenko KA, Wanner BL: One-step inactivation of chromosomal genes in Escherichia coli K-12 using PCR products. Proc Natl Acad Sci USA 2000, 97(12):6640-6645.

17. Zhou S, Shanmugam KT, Ingram LO: Functional replacement of the Escherichia coli d-(-)-lactate dehydrogenase gene (IdhA) with the I-(+)-lactate dehydrogenase gene (IdhL) from Pediococcus acidilactici. Appl Environ Microbiol 2003, 69(4):2237-2244.

18. Shinkawa S, Okano K, Yoshida S, Tanaka T, Ogino C, Fukuda H, Kondo A: Improved homo L-lactic acid fermentation from xylose by abolishment of the phosphoketolase pathway and enhancement of the pentose phosphate pathway in genetically modified xylose-assimilating Lactococcus lactis. Appl Microbiol Biotechnol 2011, 91:1537-1544.

19. Okano K, Tanaka T, Ogino C, Fukuda H, Kondo A: Biotechnological production of enantiomeric pure lactic acid from renewable resources: recent achievements, perspectives, and limits. Appl Microbiol Biotechnol 2010, 85(3):413-423.

20. Posfai G, Koob MD, Kirkpatrick HA, Blattner FR: Versatile insertion plasmids for targeted genome manipulations in bacteria: isolation, deletion, and rescue of the pathogenicity island LEE of the Escherichia coli 0157:H7 genome. J Bacteriol 1999, 179:4426-4428.

doi:10.1186/1475-2859-12-57

Cite this article as: Zhao et al: Homofermentative production of optically pure L-lactic acid from xylose by genetically engineered Escherichia coli B. Microbial Cell Factories 2013 12:57.

\section{Submit your next manuscript to BioMed Central and take full advantage of:}

- Convenient online submission

- Thorough peer review

- No space constraints or color figure charges

- Immediate publication on acceptance

- Inclusion in PubMed, CAS, Scopus and Google Scholar

- Research which is freely available for redistribution

Submit your manuscript at www.biomedcentral.com/submit
Ciomed Central 